Article

\title{
Biomass Waste Carbonization in Piranha Solution: A Route to Hypergolic Carbons?
}

\author{
Nikolaos Chalmpes ${ }^{1, *(\mathbb{D})}$, Maria Baikousi ${ }^{1}$, Theodosis Giousis ${ }^{1,2}$, Petra Rudolf ${ }^{2} \mathbb{D}$, Constantinos E. Salmas ${ }^{1}{ }^{(D)}$, \\ Dimitrios Moschovas ${ }^{1}$, Apostolos Avgeropoulos ${ }^{1}$ (D), Athanasios B. Bourlinos ${ }^{3, *}$, Iosif Tantis ${ }^{4}$ (D), \\ Aristides Bakandritsos ${ }^{4,5}$ (D) Dimitrios Gournis ${ }^{1, *(D)}$ and Michael A. Karakassides ${ }^{1}$ (D)
}

1 Department of Materials Science \& Engineering, University of Ioannina, 45110 Ioannina, Greece; mbaikou@uoi.gr (M.B.); tgiousis@gmail.com (T.G.); ksalmas@uoi.gr (C.E.S.); dmoschov@uoi.gr (D.M.); aavger@uoi.gr (A.A.); mkarakas@uoi.gr (M.A.K.)

2 Zernike Institute for Advanced Materials, University of Groningen, Nijenborgh 4, 9747 AG Groningen, The Netherlands; p.rudolf@rug.nl

3 Physics Department, University of Ioannina, 45110 Ioannina, Greece

4 Regional Centre of Advanced Technologies and Materials, Czech Advanced Technology and Research Institute, Palacký University, Křížkovského 511/8, 77900 Olomouc, Czech Republic; iosif.tantis@upol.cz (I.T.); a.bakandritsos@upol.cz (A.B.)

5 Nanotechnology Centre, Centre of Energy and Environmental Technologies, VŠB-Technical University of Ostrava, 17. Listopadu 2172/15, 70800 Ostrava-Poruba, Czech Republic

* Correspondence: n.chalmpes@uoi.gr (N.C.); bourlino@uoi.gr (A.B.B.); dgourni@uoi.gr (D.G.)

Citation: Chalmpes, N.; Baikousi, M.; Giousis, T.; Rudolf, P.; Salmas, C.E.; Moschovas, D.; Avgeropoulos, A.; Bourlinos, A.B.; Tantis, I.; Bakandritsos, A.; et al. Biomass Waste Carbonization in Piranha Solution: A Route to Hypergolic Carbons? Micro 2022, 2, 137-153. https://doi.org/10.3390/ micro2010009

Academic Editor: Carlo Santulli

Received: 3 January 2022

Accepted: 24 January 2022

Published: 28 January 2022

Publisher's Note: MDPI stays neutral with regard to jurisdictional claims in published maps and institutional affiliations.

Copyright: (C) 2022 by the authors. Licensee MDPI, Basel, Switzerland. This article is an open access article distributed under the terms and conditions of the Creative Commons Attribution (CC BY) license (https:// creativecommons.org/licenses/by/ $4.0 /)$.

\begin{abstract}
In the present work we report for the first time the carbonization of biomass waste, such as stale bread and spent coffee, in piranha solution $\left(\mathrm{H}_{2} \mathrm{SO}_{4}-\mathrm{H}_{2} \mathrm{O}_{2}\right)$ at ambient conditions. Carbonization is fast and exothermic, resulting in the formation of carbon nanosheets at decent yields of $25-35 \%$, depending on the starting material. The structure and morphology of the nanosheets were verified by X-ray diffraction, Raman, X-ray photoelectron and microscopy techniques. Interestingly, the obtained carbon spontaneously ignites upon contact with fuming nitric acid $\mathrm{HNO}_{3}$ at ambient conditions, thus offering a rare example of hypergolicity involving carbon as the solid fuel (i.e., hypergolic carbon). Based on the relatively large interlayer spacing of the as-produced carbons, a simple structural model is proposed for the observed hypergolicity, wherein $\mathrm{HNO}_{3}$ molecules fit in the gallery space of carbon, thus exposing its basal plane and defect sites to a spontaneous reaction with the strong oxidizing agent. This finding may pave the way towards new type hypergolic propellants based on carbon, the latter exclusively obtained by the carbonization of biomass waste in piranha solution.
\end{abstract}

Keywords: stale bread; spent coffee; biomass waste; piranha solution; carbonization; fuming nitric acid; hypergolic carbon

\section{Introduction}

Piranha solution is a powerful oxidizing agent that is typically made of concentrated sulfuric acid $\left(\mathrm{H}_{2} \mathrm{SO}_{4}\right)$ and $30 \%$ hydrogen peroxide $\left(\mathrm{H}_{2} \mathrm{O}_{2}\right)$ at a 3:1 ratio. The solution tends to attack organic matter, particularly carbohydrates, through the dehydration of the organic molecules into carbon and the subsequent etching of the as-produced carbon into $\mathrm{CO}_{2}$ by in situ formed oxygen radicals. The overall result is combustion of the organic molecules into $\mathrm{CO}_{2}$ and $\mathrm{H}_{2} \mathrm{O}$ at room temperature without flame (e.g., a sort of cold combustion). As is common in every combustion process, an excess of oxygen and hence, an excess of piranha solution will lead to the complete combustion and etching of the organic matter, whereas an oxygen shortage and hence, a shortage of piranha solution will lead to the incomplete combustion and formation of char-like carbons. The advantages of the piranha solution treatment are that it takes place at ambient conditions without pyrolysis, and it is fast and exothermic, liberating energy that can be converted into useful work, and lastly, the released greenhouse $\mathrm{CO}_{2}$ gas can be collected at ambient conditions without escaping 
into open air. Disadvantages include high toxicity and corrosiveness, safety issues related to use and disposal, as well as loss of strength over time; the latter implies that freshly prepared solutions must be used. Therefore, careful handling is necessary before, during and after use in a particular process.

Despite these disadvantages, due to its strong oxidizing power, piranha solution finds numerous practical uses in the microelectronics industry for cleaning/modifying the surface of silicon wafers or for etching copper from printed circuit boards and in the chemistry laboratory for cleaning glassware, as well as in the hydrophilization of glass by creating surface silanol $\mathrm{Si}-\mathrm{OH}$ groups that are easily post-functionalized, e.g., through silanization by organofunctional alkoxysilanes. Moreover, this mixture, which also goes under the name of piranha etch, serves in carbon materials synthesis either in producing advanced carbon nanomaterials, such as graphene and photoluminescent carbon dots [1,2], or in treating the surface of carbon materials (graphene oxide nanosheets, nanotubes, fibers) to induce the formation of oxidized derivatives with tailored properties suitable for applications in cell labeling, energy and composites [3-6].

Stale bread and spent coffee are common biomass food wastes produced in large quantities. Characteristically, nearly 900,000 tonnes of bread and 6,000,000 tonnes of spent coffee end up annually in landfills worldwide before their full potential is exploited. This motivates on-going research interest for utilizing this waste as a resource for biogas/biofuel production or for the extraction of useful chemicals [7-10]. Bread and spent coffee wastes have also been employed as starting material for the development of advanced functional carbon materials with interesting properties, often produced via conventional pyrolytic or hydrothermal carbonization methods [11-16]. However, to the best of our knowledge, no report on bread and coffee biomass waste carbonization in piranha solution has been published so far. Interestingly, bread and coffee contain a significant fraction of carbohydrates, proteins and fats $[17,18]$ that are all prone to carbonization by piranha solution. Therefore, this procedure merits further attention as it could provide an alternative processing method to pyrolysis or hydrothermal treatment, yielding carbons with unique properties not achievable by conventional carbonization methods.

Herein, we present for the first time the carbonization of stale bread and spent coffee wastes in piranha solution, resulting in the formation of carbon nanosheets. The nanosheets exhibit relatively high interlayer spacing $\left(\mathrm{d}_{002}>4 \AA\right.$ ), a result of released $\mathrm{CO}_{2}$ hot gas pushing the carbon layers apart from each other. This allows $\mathrm{HNO}_{3}$ molecules to intercalate carbon, thus reaching its basal space and defect sites to trigger the hypergolic ignition of the solid at ambient conditions. The observed carbon hypergolicity is a rare phenomenon in the literature and appears to be quite unique to the present piranha solution treatment. In this respect, biomass waste carbonization in piranha solution is expected to pave the way towards the future advancement of a larger series of chemically ignitable carbons as part of a new generation of hypergolic propellants.

\section{Materials and Methods}

All syntheses were conducted in a fume hood. Concentrated $\mathrm{H}_{2} \mathrm{SO}_{4} 98 \%$ and $\mathrm{H}_{2} \mathrm{O}_{2}$ 30\% were supplied by Merck KGaA, Darmstadt, Germany. Piranha solution is highly corrosive and should be handled with great caution inside a fume hood.

In the case of bread, a cut slice of stale bread weighing a total of $30 \mathrm{~g}$ was immersed in $100 \mathrm{~mL}$ piranha solution $\left(3: 1,75 \mathrm{~mL} \mathrm{H}_{2} \mathrm{SO}_{4} 98 \%-25 \mathrm{~mL} \mathrm{H}_{2} \mathrm{O}_{2} 30 \%\right)$ as shown in the setup of Figure 1. The fast (within 5-10 min) and exothermic reaction that took place led to pieces of homogeneously carbonized bread. The pieces were washed with de-ionized water until neutral $\mathrm{pH}$, with acetone until no coloration of the solvent was observed and with dimethylformamide (DMF, Sigma-Aldrich, St. Louis, MO, USA) until no coloration of that solvent was observed. DMF is a highly polar solvent capable of washing away organic species that strongly adhere to the carbon surface. After washing with DMF, the sample was once again washed with water and acetone in order to remove the polar solvent, air-dried at $100{ }^{\circ} \mathrm{C}$ 
and crushed into a fine black powder with a yield of $25 \%$ (specific surface area from $\mathrm{N}_{2}$ BET was $10-15 \mathrm{~m}^{2} \mathrm{~g}^{-1}$ ). The sample is thereafter denoted as BRPS (from BRead-Piranha Solution).

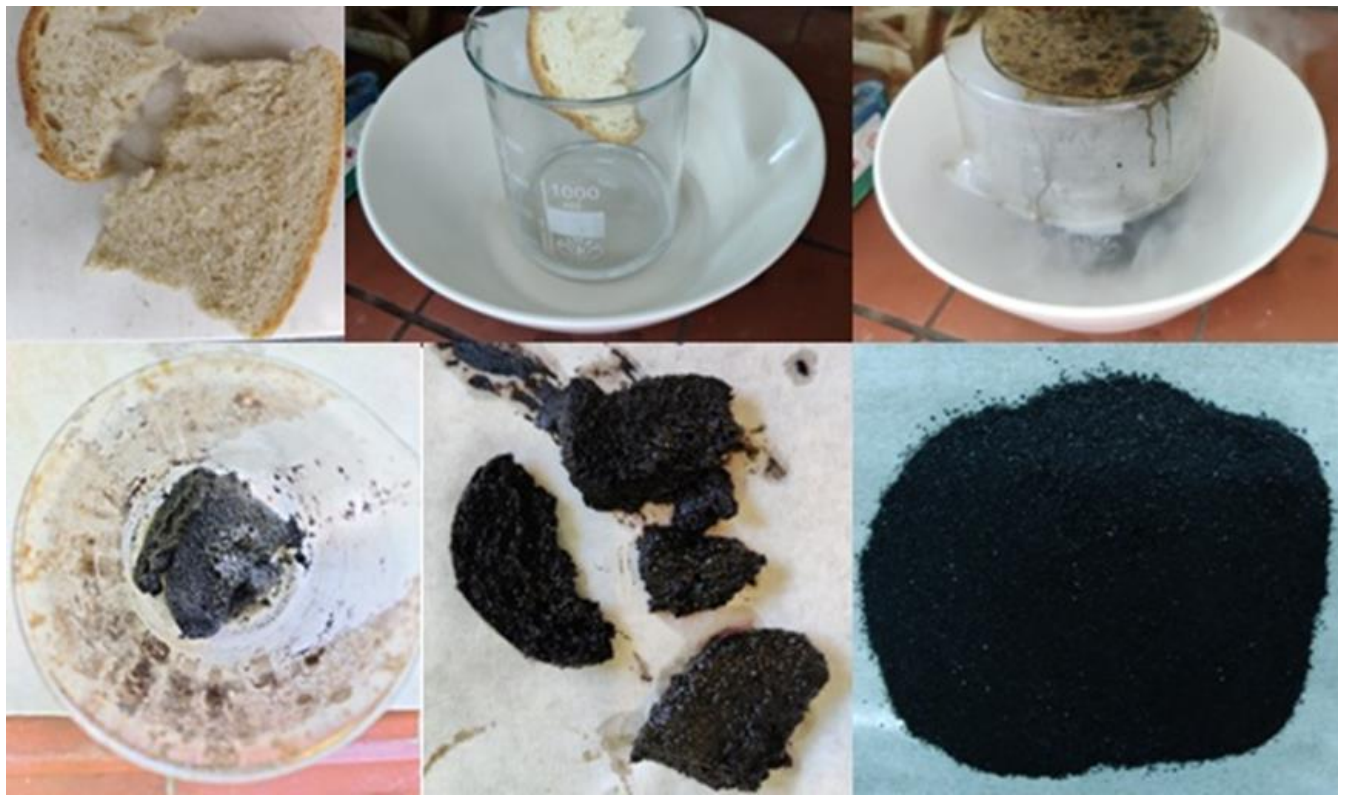

Figure 1. From top-left to bottom-right: stale bread carbonization in piranha solution, followed by washing and drying, led to a fine carbon powder (codenamed BRPS) with a yield of $25 \%$.

In the case of spent coffee, $40 \mathrm{~g}$ of dried spent coffee grains (from brewed coffee, brand name JACOBS DECAF) were slowly added in $100 \mathrm{~mL}$ piranha solution $\left(3: 1,75 \mathrm{~mL} \mathrm{H}_{2} \mathrm{SO}_{4} 98 \%\right.$ $25 \mathrm{~mL} \mathrm{H}_{2} \mathrm{O}_{2} 30 \%$ ) as shown in Figure 2. Similarly as above, the fast and exothermic reaction that took place led to a homogeneous carbonization of the spent coffee grains. The carbonized solid was rinsed with de-ionized water until neutral $\mathrm{pH}$, with acetone until no coloration of the solvent was observed and with N-methyl-2-pyrrolidone (NMP, Sigma-Aldrich, St. Louis, MO, USA) until no coloration of that solvent was observed. NMP is another highly polar solvent capable of washing away organic species that strongly adhere to the carbon surface. After washing with NMP, the sample was once again washed with water and acetone in order to remove the polar solvent, air-dried at $100^{\circ} \mathrm{C}$ and crushed into a fine black powder with a yield of $35 \%$ (the specific surface area from $\mathrm{N}_{2}$ BET was $10-15 \mathrm{~m}^{2} \mathrm{~g}^{-1}$ ). The sample is thereafter denoted as SCPS (from Spent Coffee-Piranha Solution).
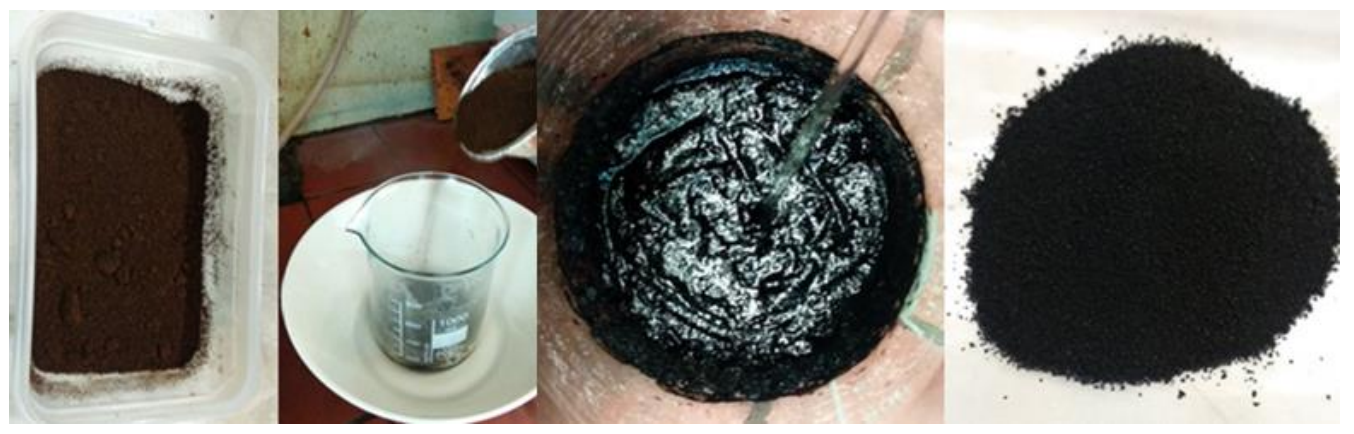

Figure 2. From left to right: spent coffee carbonization in piranha solution, followed by washing and drying, led to a fine carbon powder (codenamed SCPS) with a yield of $35 \%$.

At this point it should be mentioned that washing is an inevitable part of this method in order to obtain products with a well-defined structure and composition. Typically, nearly half a liter of a solvent is used in order to purify the carbon product. Taking into consideration 
that this waste processing also creates solvent waste, the sustainability and viability of the method should be taken seriously into consideration in terms of large-scale production.

On the other hand, the piranha solution acts through the following cascade of reactions towards carbonization as shown in Scheme 1 (https:/ / en.wikipedia.org/wiki/Piranha_ solution, last accessed on 15 January 2021):

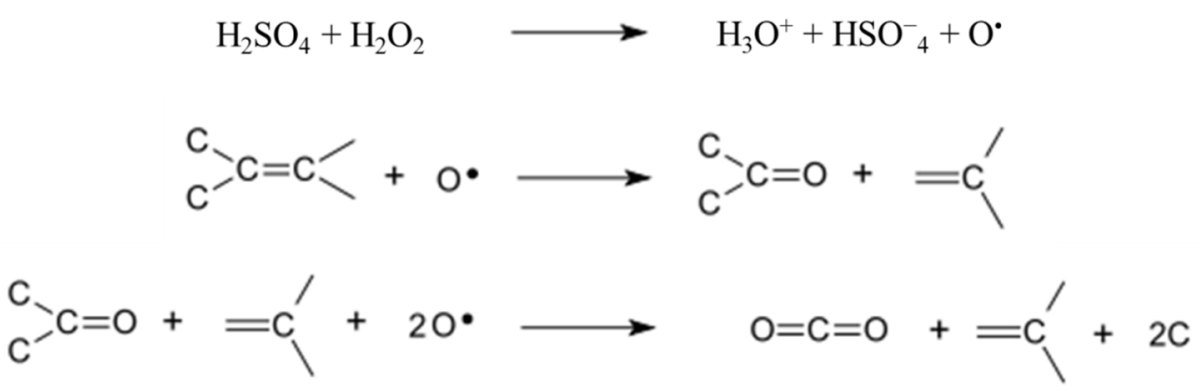

Scheme 1. Chemical reactions taking place in the piranha solution process towards carbonization, wherein the reactive oxygen radicals formed in the first reaction attack double bonds to form carbonyl groups, which further react with oxygen radicals to release $\mathrm{CO}_{2}$ and carbon. This reaction mechanism explains the loss of carbon in the form of $\mathrm{CO}_{2}$ gas during the process. Additionally, the formation of washable brown solubles further decreases the carbon yield. Such byproducts with an unknown structure are expected on account of the complex chemical compositions of bread and coffee.

X-ray diffraction (XRD) was conducted on background-free Si wafers using $\mathrm{Cu} \mathrm{K} \alpha$ radiation $(\lambda=1.54 \AA$ ) with a Bruker Advance D8 diffractometer (Bruker, Billerica, MA, USA). Raman spectra were recorded with a RM 1000 Renishaw micro-Raman system using a laser excitation line at $532 \mathrm{~nm}(\mathrm{Nd}: \mathrm{YAG})$ in the range of $100-4000 \mathrm{~cm}^{-1}$. A laser power of $10 \mathrm{~mW}$ was used with a $2 \mu \mathrm{m}$ focus spot. X-ray photoelectron spectroscopy (XPS) was performed with a SSX-100 (Surface Science Instruments) spectrometer, equipped with a monochromatic $\mathrm{Al} \mathrm{K} \alpha \mathrm{X}$-ray source $(\mathrm{h} v=1486.6 \mathrm{eV})$ and operating at a pressure of $1 \times 10^{-9}$ mbar. The samples were pressed onto silver plates; a flood gun was used to neutralize charging effects due to the insulating nature of the samples. The photoelectron take-off angle was $37^{\circ}$ with respect to the surface normal. The analyzed spot size on the sample was $1000 \mu \mathrm{m}$ in diameter. The experimental resolution was set to $1.67 \mathrm{eV}$ for overview spectra and to $1.26 \mathrm{eV}$ for the detailed scans of the various core level regions. Binding energies are reported $\pm 0.1 \mathrm{eV}$ and referenced to the $\mathrm{C} 1 \mathrm{~s}$ signal at a binding energy (BE) of 284.6 eV. All XPS spectra were analyzed using the least squares curve-fitting program Winspec (developed at LISE, University of Namur, Namur, Belgium). Deconvolution of the spectra included a Shirley background subtraction and fitting with a minimum number of peaks consistent with the chemical structure of the sample, taking into account the experimental resolution. The profile of the peaks was taken as a convolution of Gaussian and Lorentzian functions. At least 3 spots on the sample were analyzed, in order to verify the homogeneity of the sample. The uncertainty in the peak intensity determination was $2 \%$ for all core levels reported. Scanning electron microscopy (SEM) images were obtained using a JSM-6510 LV SEM Microscope (JEOL Ltd., Tokyo, Japan) equipped with an X-Act EDS-detector by Oxford Instruments (Abingdon, Oxfordshire, UK, an acceleration voltage of $20 \mathrm{kV}$ was applied). The samples were studied using transmission electron microscopy TEM (JEOL 2010 TEM equipped with $\mathrm{a} \mathrm{LaB}_{6}$ type emission gun operating at $160 \mathrm{kV}$, JEOL Ltd., Tokyo, Japan). Scanning transmission electron microscopy high-angle annular darkfield (HAADF) imaging analyses for the EDS mapping of elemental distributions on the products were performed with a FEI Titan HR-TEM microscope operating at $80 \mathrm{kV}$. Atomic force microscopy (AFM) images were collected in tapping mode with a Bruker Multimode 3D Nanoscope (Ted Pella Inc., Redding, CA, USA) using a microfabricated silicon cantilever type TAP-300G, with a tip radius of $<10 \mathrm{~nm}$ and a force constant of ca. $20-75 \mathrm{~N} \mathrm{~m}^{-1}$. The Si wafers (P/Bor, single-side polished, Si-Mat, Kaufering, Germany) used in AFM 
imaging were cleaned before use for $20 \mathrm{~min}$ in an ultrasonic bath $(160 \mathrm{~W})$ with water, acetone ( $\geq 99.5 \%$ Sigma-Aldrich, St. Louis, MO, USA) and ethanol ( $\geq 99.5 \%$ Sigma-Aldrich, St. Louis, MO, USA).

\section{Results}

\subsection{Structural Characterization and Morphology}

The powder XRD patterns of BRPS and SCPS (Figure 3, top) show broad (002) reflections with corresponding interlayer spacings of $\mathrm{d}_{002}=4.3 \AA$ and $\mathrm{d}_{002}=4.4 \AA$, respectively. Such spacings are larger than that of crystalline graphite $\left(\mathrm{d}_{002}=3.4 \AA\right.$ [19] $)$ and due to the generation of hot $\mathrm{CO}_{2}$ gas that pushes the carbon layers apart from each other. The broadness of the reflections along with the relatively high $\mathrm{d}_{002}$ values pinpoints the formation of amorphous carbons adopting a turbostratic ordering of incompletely crystallized layers [20,21]. In contrast, highly crystalline graphite displays sharper reflections with smaller $\mathrm{d}_{002}$ values [19]. It is also worth noting that the $\mathrm{d}_{002}$ value of SCPS is higher than that of pyrolyzed spent coffee with $\mathrm{d}_{002}=3.5 \AA$ [16]. Based on the Scherrer equation, the $\mathrm{L}_{\mathrm{c}}$ crystallite height of the particles along the c direction was estimated at about $23 \AA$ or $2.3 \mathrm{~nm}$ for both samples, values which correspond to stacks of 6-7 carbon layers per particle [21]. On the other hand, Raman spectroscopy (Figure 3, bottom) shows the characteristic for carbon D and $G$ bands at 1356 and $1585 \mathrm{~cm}^{-1}$, respectively, with an intensity ratio $\mathrm{I}_{\mathrm{D}} / \mathrm{I}_{\mathrm{G}}=0.7$ for both samples (i.e., $>0.2$ typical for crystalline graphite [19]), indicating amorphous carbon $[20,22,23]$. Based on the $\mathrm{I}_{\mathrm{D}} / \mathrm{I}_{\mathrm{G}}$ ratio and its close relation to the $\mathrm{L}_{\alpha}$ size of the $\mathrm{sp}^{2}$ nanodomains within a layer [22], $\mathrm{L}_{\alpha}$ was estimated to be $6.3 \mathrm{~nm}$. Moreover, the broad band centered near $2900 \mathrm{~cm}^{-1}$ can either be attributed to $\mathrm{N}$ incorporation into the carbon lattice (e.g., nitrogenous carbon) [24-26] or/and to a set of broad and superimposed $\mathrm{D}+\mathrm{D}^{\prime \prime}, 2 \mathrm{D}, \mathrm{D}+\mathrm{G}$ and 2D' pre-graphite bands [19], due to incomplete carbon crystallization.

The composition of BRPS and SCPS was determined by XPS. The XPS surveys of both samples (Figure 4a,c) show intense peaks at BEs of 284.0 and $530.0 \mathrm{eV}$, which are attributed to the $\mathrm{C} 1 \mathrm{~s}$ and O1s core level lines, respectively [27]. For BRPS (Figure 4a) other peaks with significantly lower intensity are identified at BEs of 400.0, 168.0, 51.0 and $31.0 \mathrm{eV}$; they correspond to the N1s, S2p, Mg2p and Na2p core level lines and are typical for the composition of bread [28]. For SCPS (Figure 4c), the XPS survey, in addition to the main elements $\mathrm{C}$ and $\mathrm{O}$, showed the signature of $\mathrm{N}$ and $\mathrm{S}$ at BEs of 400.0 and $168.0 \mathrm{eV}$, respectively, in agreement with the typical elemental composition of coffee waste [29]. The C1s spectrum for BRPS (Figure 4b) needs six components to achieve a good fit; this implies that, at a BE $282.9 \mathrm{eV}, \mathrm{C}-\mathrm{Me}(\mathrm{Me}: \mathrm{Mg}, \mathrm{Na}$ ) bonds contribute with $10 \%$ to the total carbon intensity; at $284.5 \mathrm{eV}, \mathrm{C}-\mathrm{C}$ bonds are responsible for $18.2 \%$; at $286.1 \mathrm{eV}$, C-S bonds are responsible for $21.8 \%$; at $287.6 \mathrm{eV}, \mathrm{C}-\mathrm{O} / \mathrm{C}-\mathrm{N}$ bonds are responsible for $34.4 \%$; $\mathrm{C}=\mathrm{O}$ at $289.6 \mathrm{eV}$ for $11.1 \%$ and $\mathrm{O}-\mathrm{C}=\mathrm{O}$ at $291.6 \mathrm{eV}$ contribute with $4.4 \%$ [30,31]. On the other hand, the deconvolution of the C1s spectrum for SCPS necessitates four components (Figure 4d); the signal at a BE of $284.6 \mathrm{eV}$ is attributed to $\mathrm{C}-\mathrm{C}$ bonds and amounts to $56.7 \%$ of the total C1s intensity; the signal at $285.8 \mathrm{eV}$ stems from C-S bonds (relative intensity $30.6 \%$ ); the one at $287.4 \mathrm{eV}$ is assigned to $\mathrm{C}-\mathrm{O} / \mathrm{C}-\mathrm{N}$ bonds $(7.8 \%)$, and, at $289.3 \mathrm{eV}$, one finds the contribution of $\mathrm{C}=\mathrm{O}$ bonds accounting for $4.9 \%$ of the carbon signal [32,33].

The morphology of the BRPS and SCPS samples was assessed by SEM and TEM electron microscopies, showing the presence of plate-like nanometer-sized flakes with multilayer structure (Figure 5). From the height profiles of the AFM examination, the thickness of the flakes was estimated to be circa $3 \mathrm{~nm}$ (Figure 6), i.e., close to the $\mathrm{L}_{\mathrm{c}}$ crystallite height calculated from $X$-ray diffraction $(2.3 \mathrm{~nm})$.

On the other hand, chemical mapping of BRPS and SCPS (Figure 7), carried out by energy-dispersive $X$-ray spectroscopy conducted with the HR-TEM, revealed a homogeneous $\mathrm{C}, \mathrm{O}, \mathrm{N}$ and $\mathrm{S}$ elements distribution throughout the nanometer-sized flakes, thus confirming their uniform composition. 

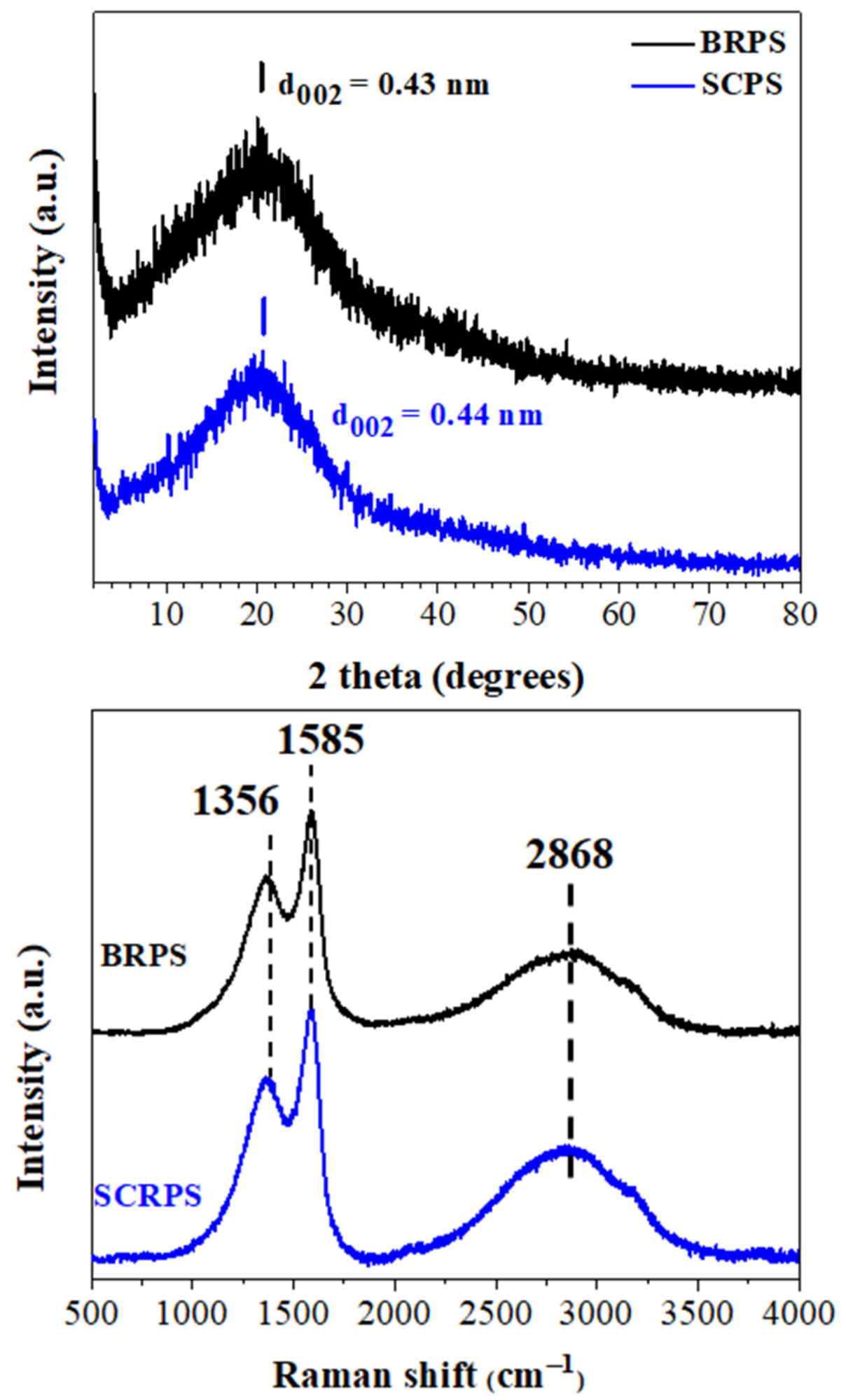

Figure 3. XRD patterns (top) and Raman spectra (bottom) of BRPS and SCPS. 
(a)

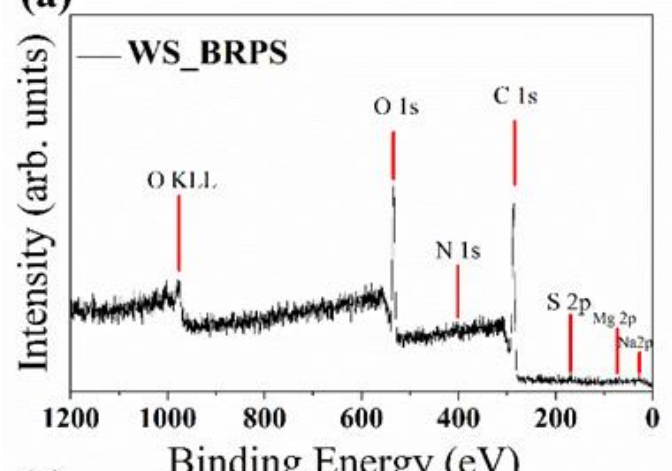

(c) Binding Energy (eV)

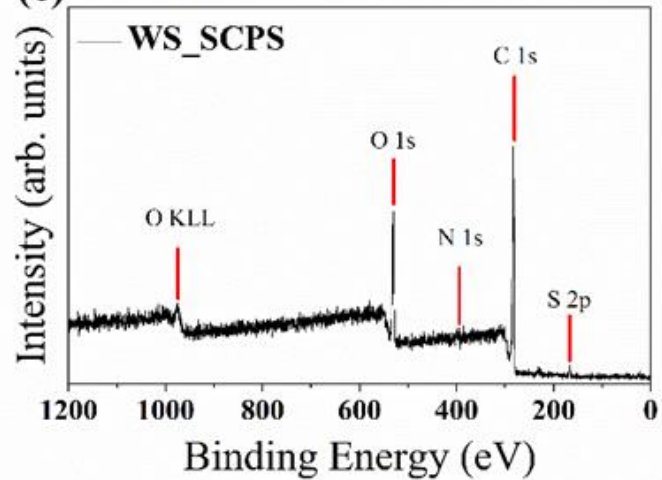

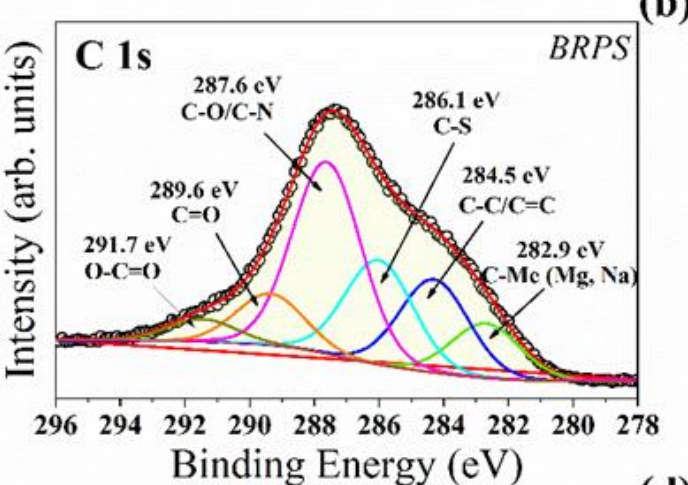

(d)

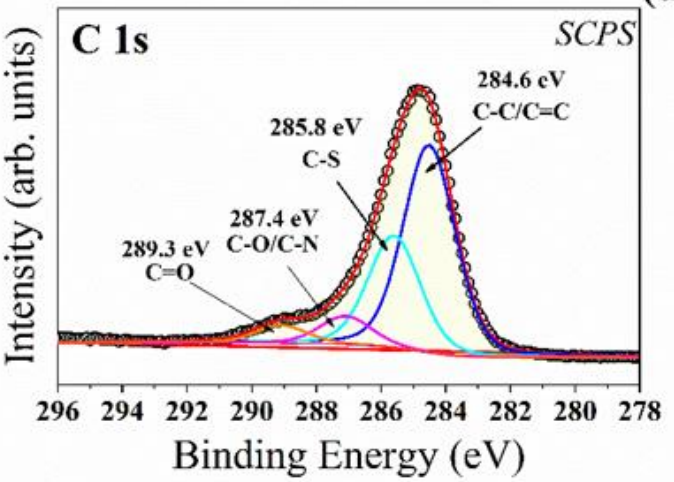

Figure 4. The XPS survey of BRPS (a) and SCPS (c). The deconvolution of XPS spectrum of the C1s core level region of BRPS (b) and SCPS (d).

These results suggest that the effects of a piranha solution treatment should also be considered for other types of waste discarded in large quantities, such as apples, potatoes, cigarette butts, medicine waste (aspirin, paracetamol) and cardboard. We started with cardboard, which produces sizeable amounts of waste in spite of recycling. For the carbonization process, $30 \mathrm{~g}$ of cardboard were first cut into small pieces and then added to $70 \mathrm{~mL}$ of piranha solution $\left(3: 1 \mathrm{H}_{2} \mathrm{SO}_{4} / \mathrm{H}_{2} \mathrm{O}_{2}\right)$. The obtained carbon was washed similarly as the BRPS and SCPS samples, except for using dimethyl sulfoxide (DMSO, Merck KGaA, Darmstadt, Germany) as a highly polar solvent. The carbon yield was $15 \%$. Once more, XRD showed a broad (002) reflection, which translates into an interlayer spacing of $4.3 \AA$; in addition the signature peaks of cellulosic residues from cardboard were detected (Figure 8 , top). On the other hand, Raman spectroscopy showed the characteristic D and G bands of carbon (Figure 8, bottom). Note that some cardboard residues in the sample could be seen by naked eye and hence could be separated by hand.

Similar trials with other waste products gave carbon yields that are too low for an economically viable exploitation, namely $0.5 \%$ for apples, $0.1 \%$ for potatoes, $5 \%$ for cigarette butts and $0.1 \%$ for medicine waste (aspirin, paracetamol).

\subsection{Carbon Hypergolicity}

Hypergolic fuels are mainly used as propellants in rocket engines and simply consist of a fuel and a strong oxidizer that ignite spontaneously upon contact at ambient conditions without external stimuli. Fuels include hydrazine derivatives, heterocyclics, long-chain aliphatics, $\mathrm{N}$-alkyl diamines, aromatics, sugars, ionic liquids, metal-organic frameworks and metal powders $\left(\mathrm{Al}, \mathrm{Mg}\right.$ ), whereas strong oxidizers include fuming nitric acid $\mathrm{HNO}_{3}$, $\mathrm{N}_{2} \mathrm{O}_{4}, \mathrm{NH}_{4} \mathrm{ClO}_{4}, \mathrm{KClO}_{3}$, concentrated $\mathrm{H}_{2} \mathrm{O}_{2}$ and $\mathrm{Na}_{2} \mathrm{O}_{2}$ to name a few [34-46]. Some criteria for hypergolic fuels are high energy value $\left(25-50 \mathrm{~kJ} \cdot \mathrm{g}^{-1}\right.$ [41]), high density (e.g., preferably solid fuels that occupy less space), inexpensiveness, low toxicity and fast ignition upon contact with a strong oxidizer. More and more often, nanocarbons such as fullerenes, 
nanotubes, graphene/graphene oxide or nanodiamonds are added as fillers in the composition of hypergolic fuels in order to boost and sustain a smooth ignition [47]. Nevertheless, none of these nanocarbons are inherently hypergolic upon contact with a strong oxidizer at ambient conditions. In fact, the phenomenon of carbon hypergolicity is quite rare in literature, and the very few cases documented comprise: activated charcoal reported to ignite upon contact with $\mathrm{Na}_{2} \mathrm{O}_{2}$ in the presence of a small amount of water (see Bretherick's Handbook of Reactive Chemical Hazards); fullerenes shown to ignite upon mechanochemical mixing with $\mathrm{Na}_{2} \mathrm{O}_{2}$ [48]; fine carbon dust, which can explode in air under certain circumstances [49]; coal found to ignite and burn upon contact with $\mathrm{F}_{2}$ gas at ambient conditions [50]; and carbon nanotubes, for which flash ignition was shown [51]. Another example not to be forgotten is "pyrophoric carbon" [52,53], a self-ignitable form of carbon obtained from the mild pyrolysis of cut herbage at $250-300{ }^{\circ} \mathrm{C}$. In all these cases, carbon ignition takes place spontaneously at ambient conditions without external stimuli. Although carbon materials have high energy value (ca. $\left.30 \mathrm{~kJ} \cdot \mathrm{g}^{-1}\right)$, low cost and low toxicity, their direct application as solid propellants in rocket engines has remained largely unexplored.

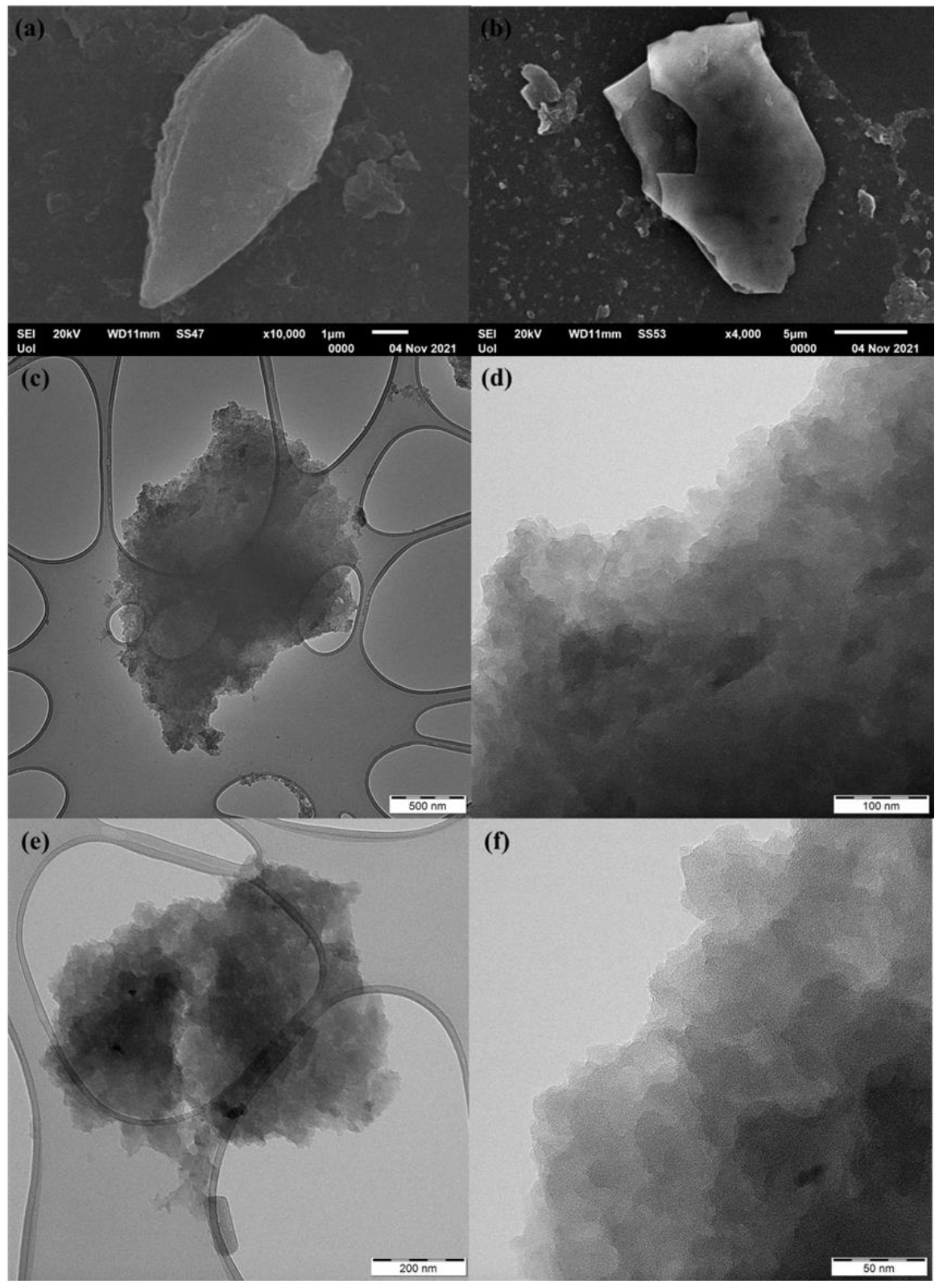

Figure 5. Representative SEM and TEM images of BRPS (a,c,d) and SCPS (b,e,f). 

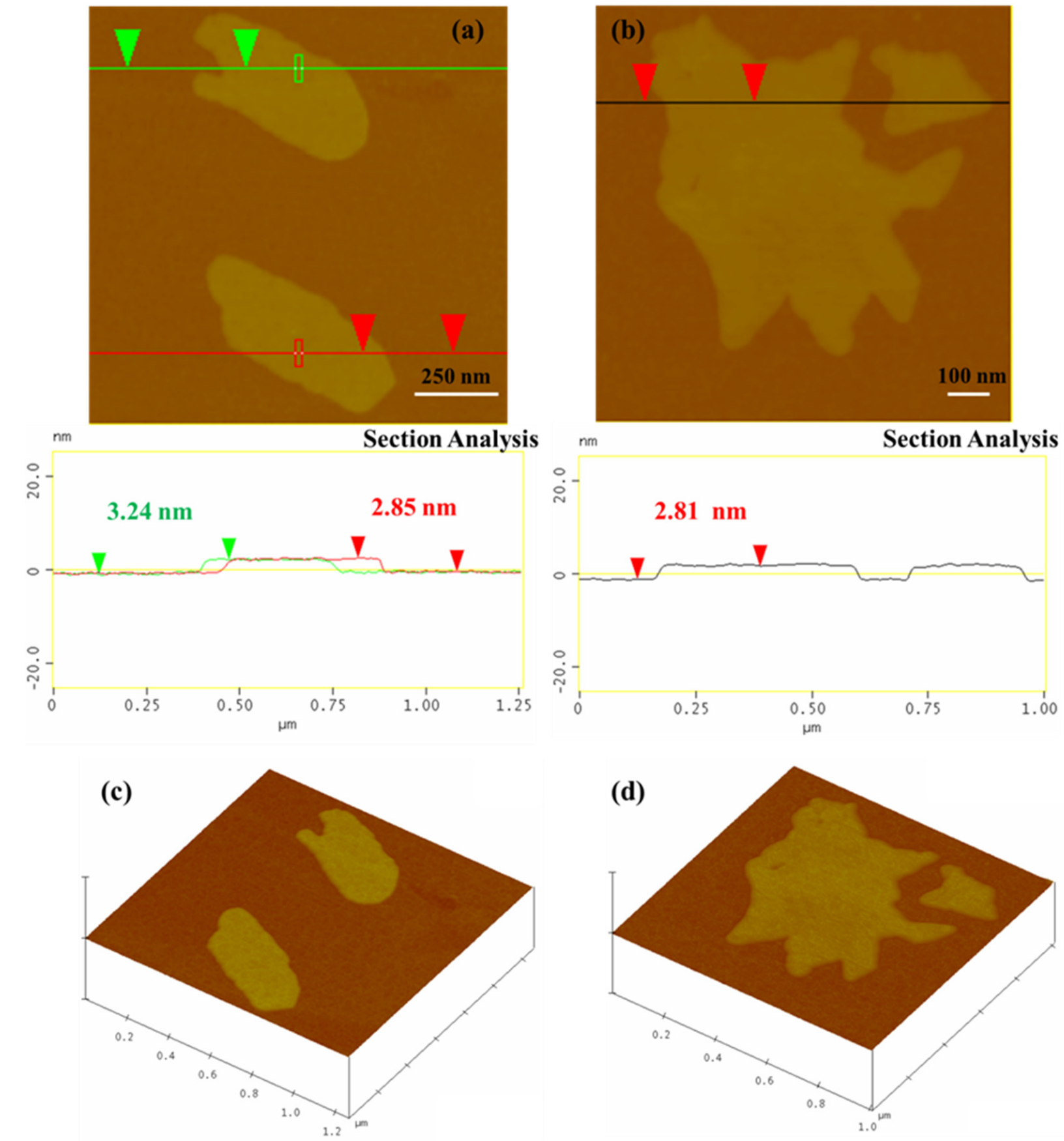

Figure 6. AFM images (top) with the corresponding cross-sectional analysis profile (center) and 3D morphology (bottom) of selected carbon nanosheets for BRPS $(\mathbf{a}, \mathbf{c})$ and SCPS $(\mathbf{b}, \mathbf{d})$.

In the current study, the carbons obtained from the piranha solution treatment of stale bread and spent coffee were shown to be inherently hypergolic when brought in contact with fuming nitric acid $\mathrm{HNO}_{3}$ (Figure 9). To this aim, $2 \mathrm{~g}$ of BRPS or SCPS were placed in an open glass vial and $3 \mathrm{~mL}$ or $5 \mathrm{~mL}$ fuming $\mathrm{HNO}_{3}(100 \%$ Sigma-Aldrich, St. Louis, $\mathrm{MO}$, USA) were added respectively. The ignition is sensitive to the amount of $\mathrm{HNO}_{3}$ : excess of nitric acid may lead to the wetting of the particles, thus inhibiting ignition (boiling point of pure $\mathrm{HNO}_{3}: 83^{\circ} \mathrm{C}$ ), while the addition of too small amounts cannot sustain ignition. After a delay time of circa $1 \mathrm{~min}$, both carbon solids ignited spontaneously at ambient conditions giving bursts of yellow flames. 


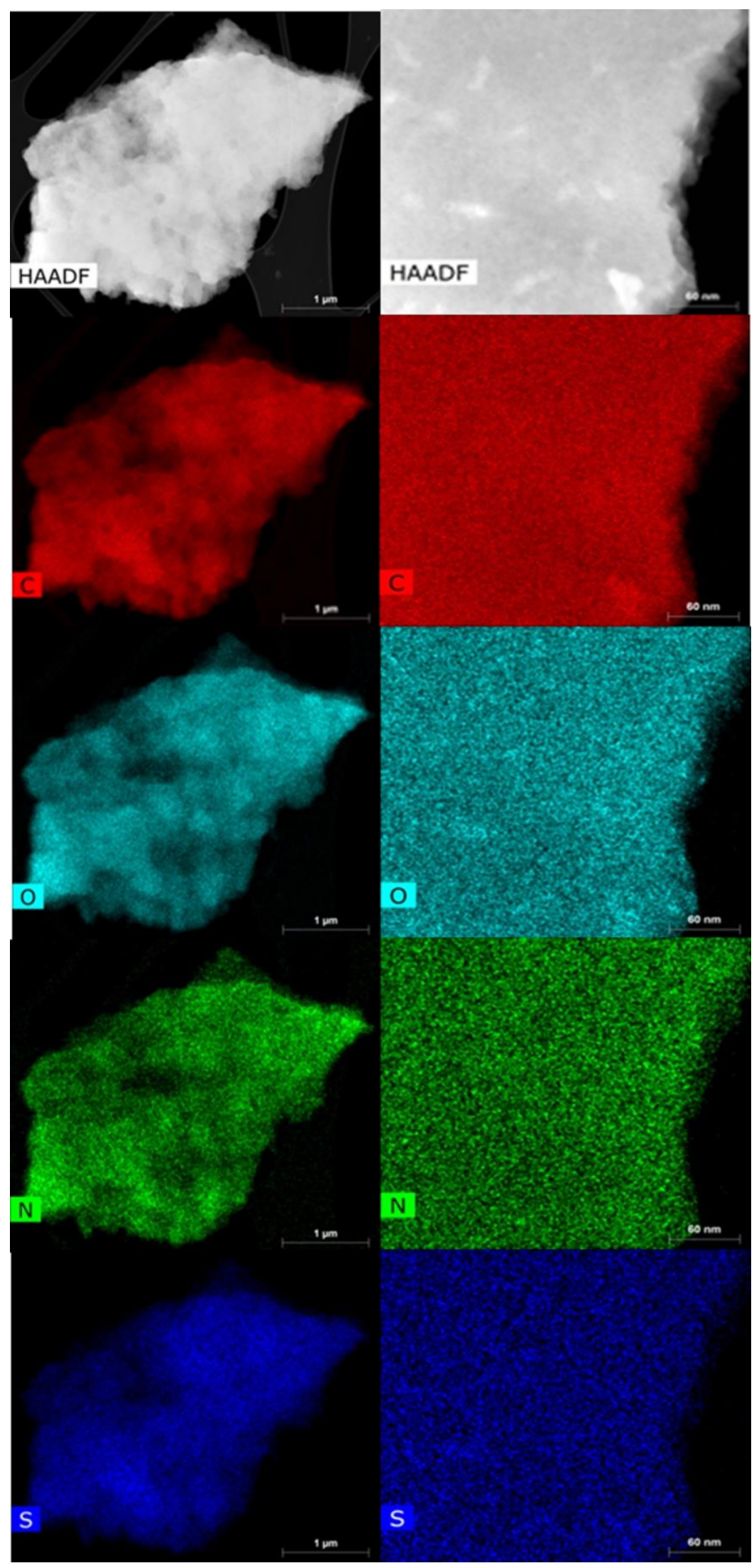

Figure 7. HR-TEM images and chemical mapping of BRPS (left column) and SCPS (right column); red denotes $\mathrm{C}$; light green-blue denotes $\mathrm{O}$; green denotes $\mathrm{N}$, and deep blue denotes $\mathrm{S}$. 

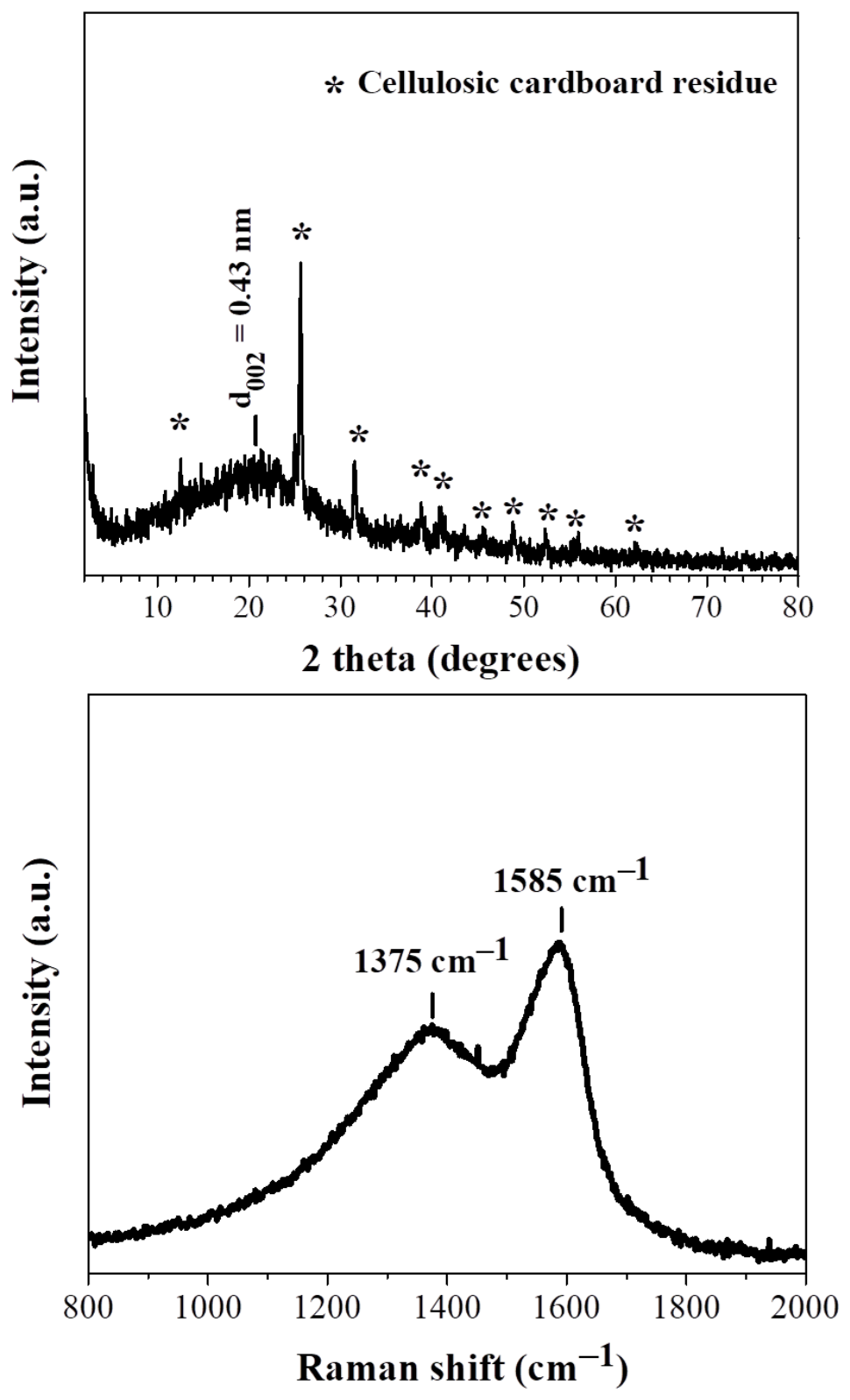

Figure 8. XRD pattern (top) and Raman spectrum (bottom) of the cardboard-derived carbon.

By assuming that the average size of $\mathrm{HNO}_{3}$ molecule is $3.5 \AA$ (i.e., close to the diameter of $\mathrm{NO}_{3}{ }^{-}$ion) and knowing that the interlayer spacing of the carbon nanosheets is $4.3 \AA$, we conclude that the $\mathrm{HNO}_{3}$ molecules match well the interlayer spacing of both carbons. Generally, nitric acid is commonly used to intercalate graphite [54]. In the present case, the larger interlayer space allows for a higher amount of $\mathrm{HNO}_{3}$ to be included between the layers. Hence, as shown in Figure 10, the strong oxidizer may easily access the basal spacing and defect sites of the carbon lattice, thus triggering ignition according to the following exothermic $\left(\Delta \mathrm{H}_{\mathrm{rxn}}{ }^{\mathrm{o}}<0\right)$ and spontaneous $\left(\Delta \mathrm{G}_{\mathrm{rxn}}{ }^{\mathrm{o}}<0\right)$ reaction at $25^{\circ} \mathrm{C}(\mathrm{T}=298 \mathrm{~K})$ $\left(\Delta \mathrm{H}_{\mathrm{rxn}}{ }^{\mathrm{o}}=-1626 \mathrm{~kJ}, \Delta \mathrm{S}_{\mathrm{rxn}}{ }^{\mathrm{o}}=+1.22 \mathrm{~kJ} \cdot \mathrm{K}^{-1}, \Delta \mathrm{G}_{\mathrm{rxn}}{ }^{\mathrm{o}}=\Delta \mathrm{H}_{\mathrm{rxn}}{ }^{\mathrm{o}}-\mathrm{T} \cdot \Delta \mathrm{S}_{\mathrm{rxn}}{ }^{\mathrm{o}}=-1990 \mathrm{~kJ}\right)$ :

$$
5 \mathrm{C}_{(\mathrm{s})}+4 \mathrm{HNO}_{3(\mathrm{l})} \rightarrow 2 \mathrm{~N}_{2(\mathrm{~g})}+5 \mathrm{CO}_{2(\mathrm{~g})}+2 \mathrm{H}_{2} \mathrm{O}(\mathrm{g})
$$




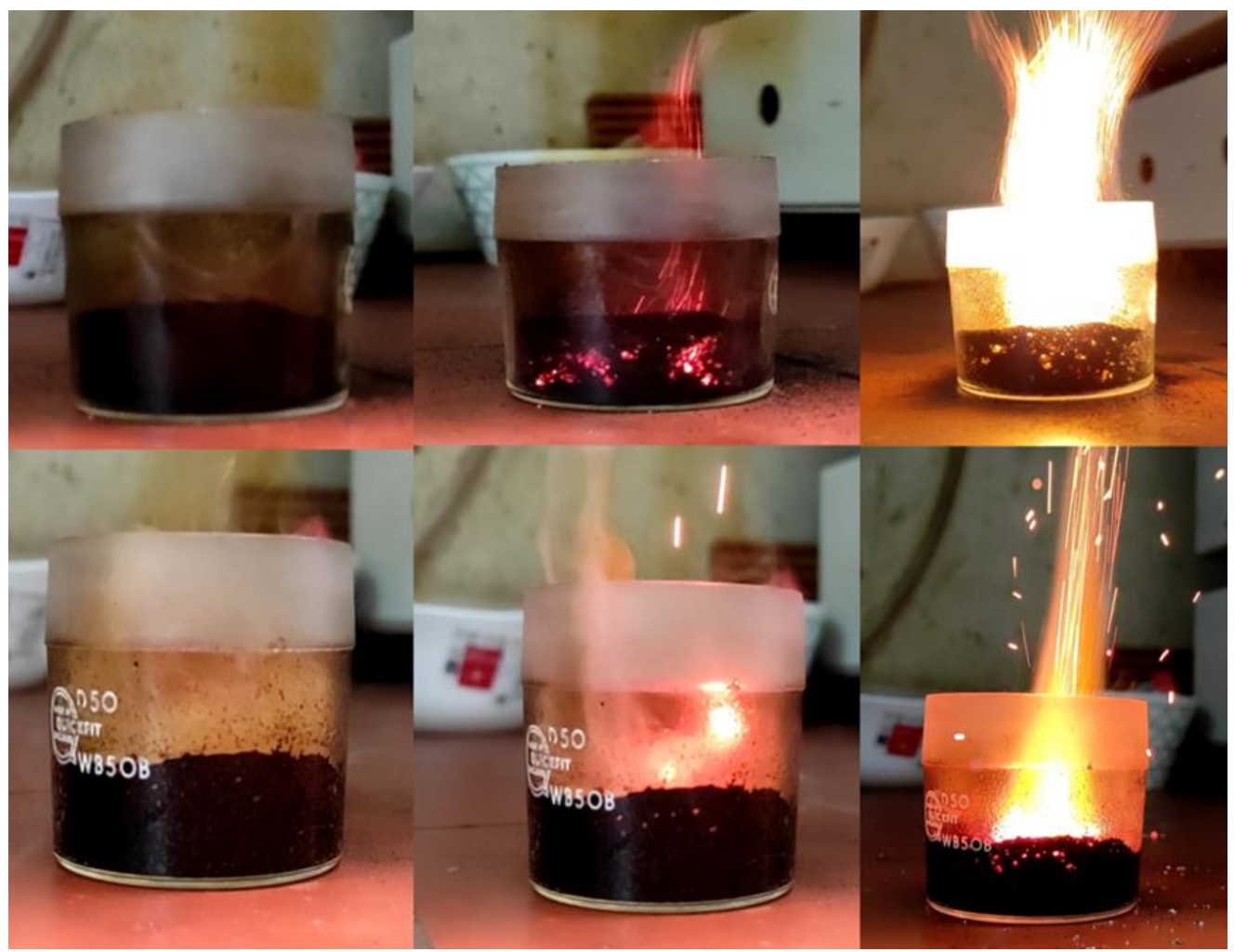

Figure 9. The addition of fuming nitric acid $\mathrm{HNO}_{3}$ to BRPS (top row) and SCPS (bottom row) leads to the hypergolic ignition of the samples at ambient conditions, thus providing a rare example of carbon hypergolicity. The duration of the ignition was $10 \mathrm{~s}$. Carbon ignition by fuming $\mathrm{HNO}_{3}$ was tested at least 3 times, each one from a different preparative batch.
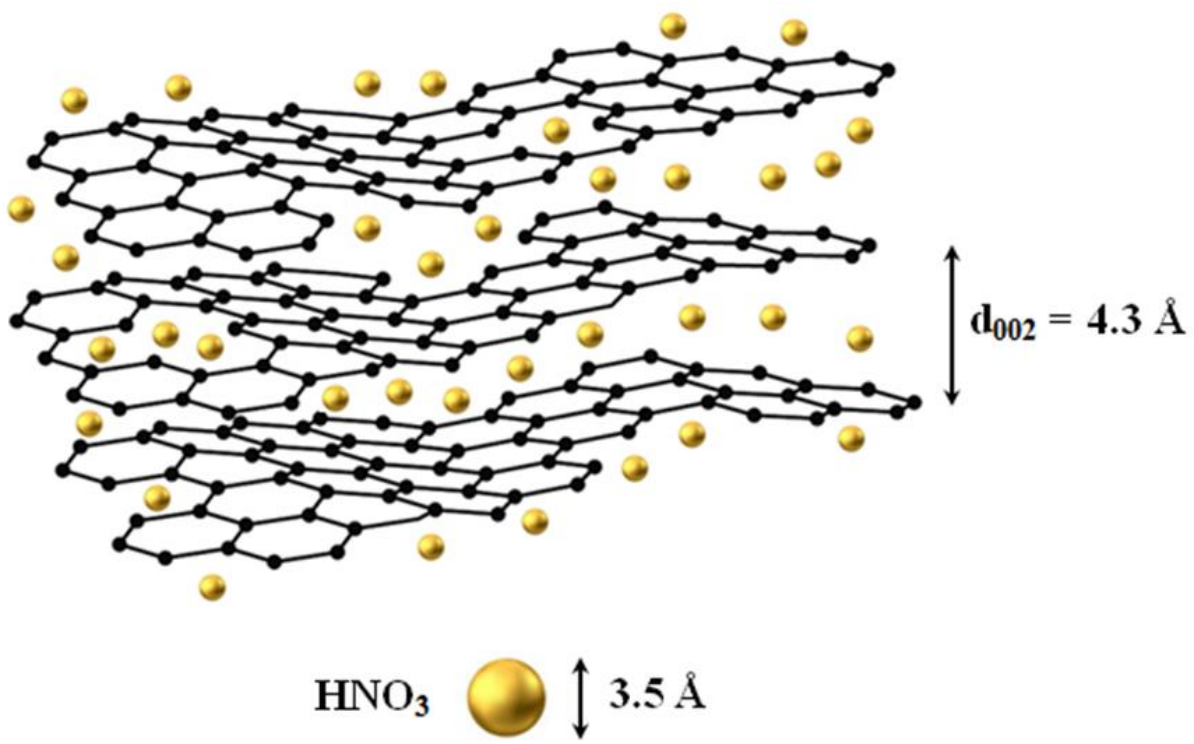

Figure 10. Schematic representation of $\mathrm{HNO}_{3}$ insertion into the gallery space of carbon. Once $\mathrm{HNO}_{3}$ reaches the carbon basal plane and defect sites, this triggers its ignition according to the spontaneous reaction presented above. For reasons of simplicity, structural heteroatoms like O, N S are not shown in the scheme. 
The above enthalpy change value compares quite well or even better to that of other hypergolic pairs used in rocket propellants, such as the $\mathrm{N}_{2} \mathrm{H}_{4}-\mathrm{H}_{2} \mathrm{O}_{2}$ system, for which holds:

$$
\mathrm{N}_{2} \mathrm{H}_{4(\mathrm{l})}+2 \mathrm{H}_{2} \mathrm{O}_{2(\mathrm{l})} \rightarrow \mathrm{N}_{2(\mathrm{~g})}+4 \mathrm{H}_{2} \mathrm{O}_{(\mathrm{g})} \quad \Delta \mathrm{H}=-780 \mathrm{~kJ}
$$

Based on the mechanism proposed in Figure 10, washing of the carbon solids with highly polar solvents (NMP, DMF or DMSO) is critical in order to remove any organic species that strongly adhere to the carbon surface, thus blocking the interlayer space. Worth noting, crystalline graphite with considerably fewer defect sites and $\mathrm{d}_{002}=3.4 \AA$ (i.e., less than the nominal size of $\mathrm{HNO}_{3}$, thus limiting influx of the latter molecules into the gallery space of carbon) gave no ignition with fuming nitric acid at any ratio. The same holds true also for pyrolyzed spent coffee discussed earlier with $\mathrm{d}_{002}=3.5 \AA$. Hence, the ignition property seems to be unique to the current piranha solution treatment. Furthermore, the proposed structural model might also explaining the observed ignition delay, e.g., $\mathrm{HNO}_{3}$ molecules need some time to diffuse into the gallery space of carbon. Although an ignition delay is undesirable in hypergolic propellants, higher surface area carbon nanosheets (porous or/and with smaller lateral dimensions) could perhaps trigger a faster ignition. Ignition with fuming nitric acid was also found for the cardboard-derived carbon (Figure 11). In this case, thermal camera imaging of the ignition process showed a maximum reached temperature of circa $300{ }^{\circ} \mathrm{C}$.

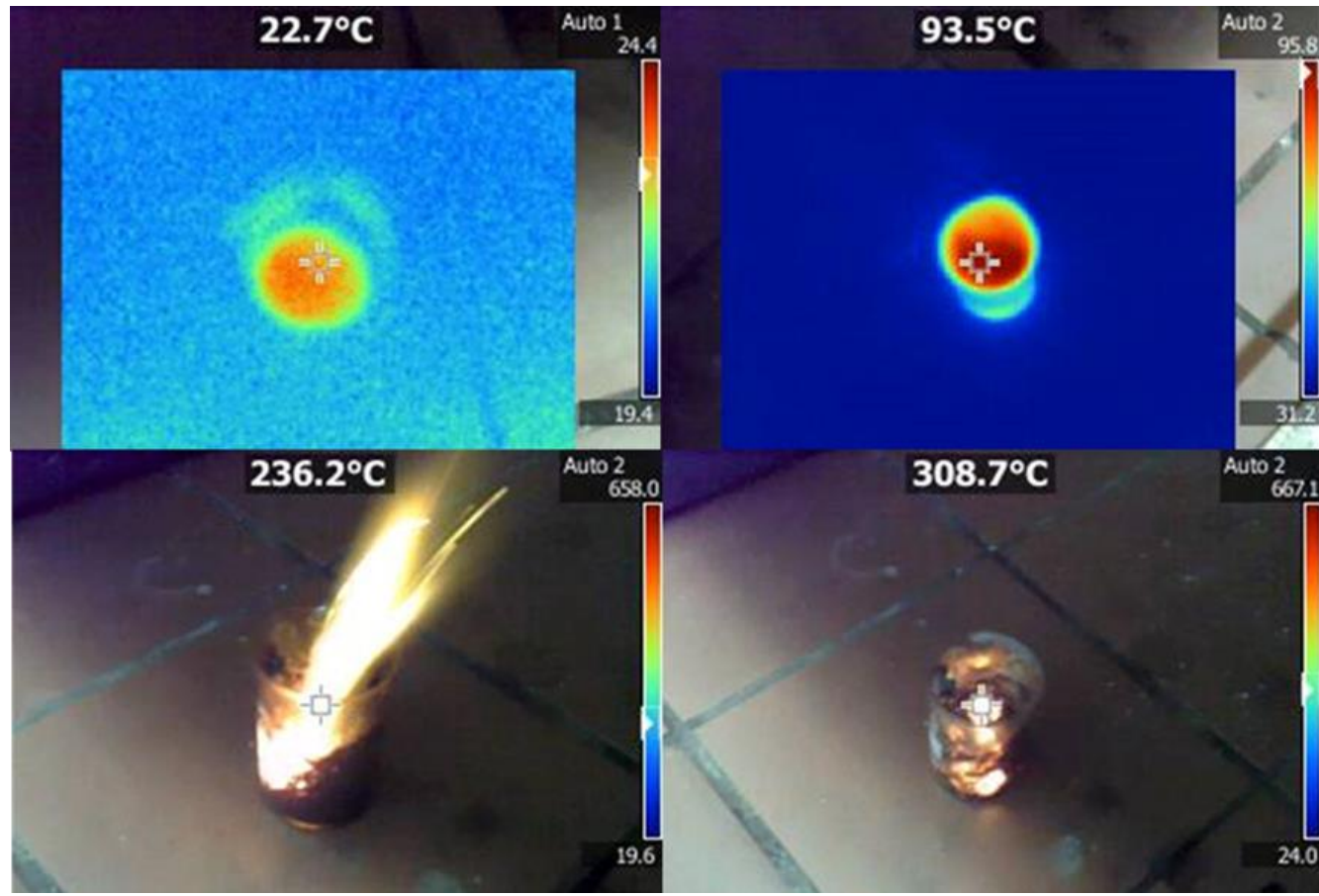

Figure 11. Digital thermal camera images depicting the gradual increase of temperature from room temperature (before the addition of fuming $\mathrm{HNO}_{3}$ ) to a maximum of circa $300{ }^{\circ} \mathrm{C}$ after adding fuming $\mathrm{HNO}_{3}$. The temperature reaches its maximum value within 2-3 s after the initiation of the ignition process.

It is interesting to note that the relatively large interlayer spacing of the derived carbons also allows for the intercalation of ignitable flat aromatic molecules (thickness circa $3.5 \AA$ ) between the nanosheets, thus further boosting carbon hypergolicity when in contact with fuming $\mathrm{HNO}_{3}$. To demonstrate this, we chose aniline $\left(\mathrm{C}_{6} \mathrm{H}_{5} \mathrm{NH}_{2}\right)$, which is well known to react hypergolically with fuming nitric acid $\mathrm{HNO}_{3}$ [55-57]. A total of $1.5 \mathrm{~g}$ of the cardboard-derived carbon was mixed with $1.5 \mathrm{~g}$ aniline (99\%, Sigma-Aldrich, St. Louis, MO, USA) in a sealed glass vial, and the mixture was placed at $100{ }^{\circ} \mathrm{C}$ for a day in an oven in order to force the aniline molecules into the gallery space of carbon. Aniline interca- 
lation was evidenced by XRD (Figure 12), wherein a small increase in interlayer spacing $\left(\mathrm{d}_{002}=4.7 \AA\right)$ and a sharpening of the (002) reflection due to better lamellar ordering were observed [58,59].

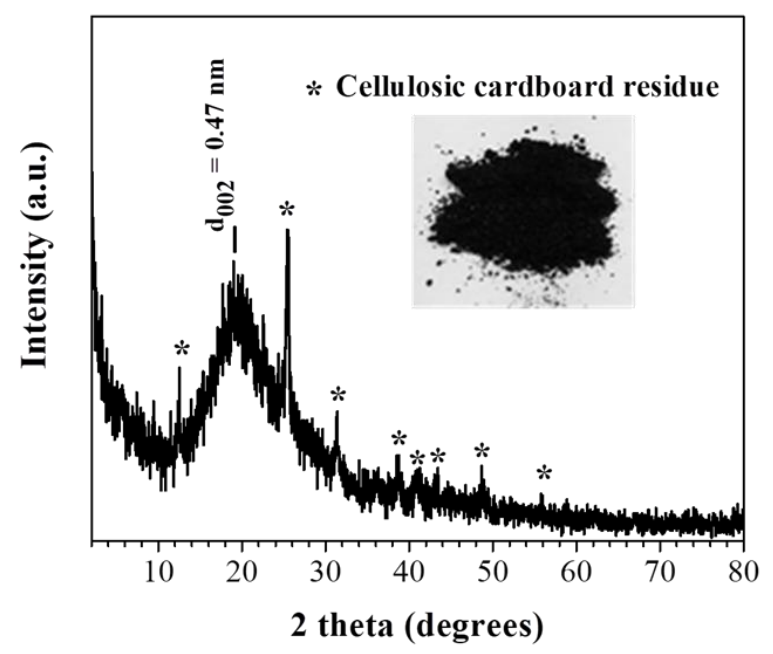

Figure 12. XRD pattern of the cardboard-derived carbon intercalated with aniline; in the inset, a photograph of the aniline-intercalated solid is shown.

The intercalated solid (2.5 g) was placed in a flask, and $2.5 \mathrm{~mL}$ fuming $\mathrm{HNO}_{3}$ was slowly added. Instantly, a bright ignition took place irrespectively of the added amount of acid (Figure 13). Therefore, aniline intercalation might eventually hold the key to overcome ignition delays and achieve faster and brighter ignitions at ambient conditions.

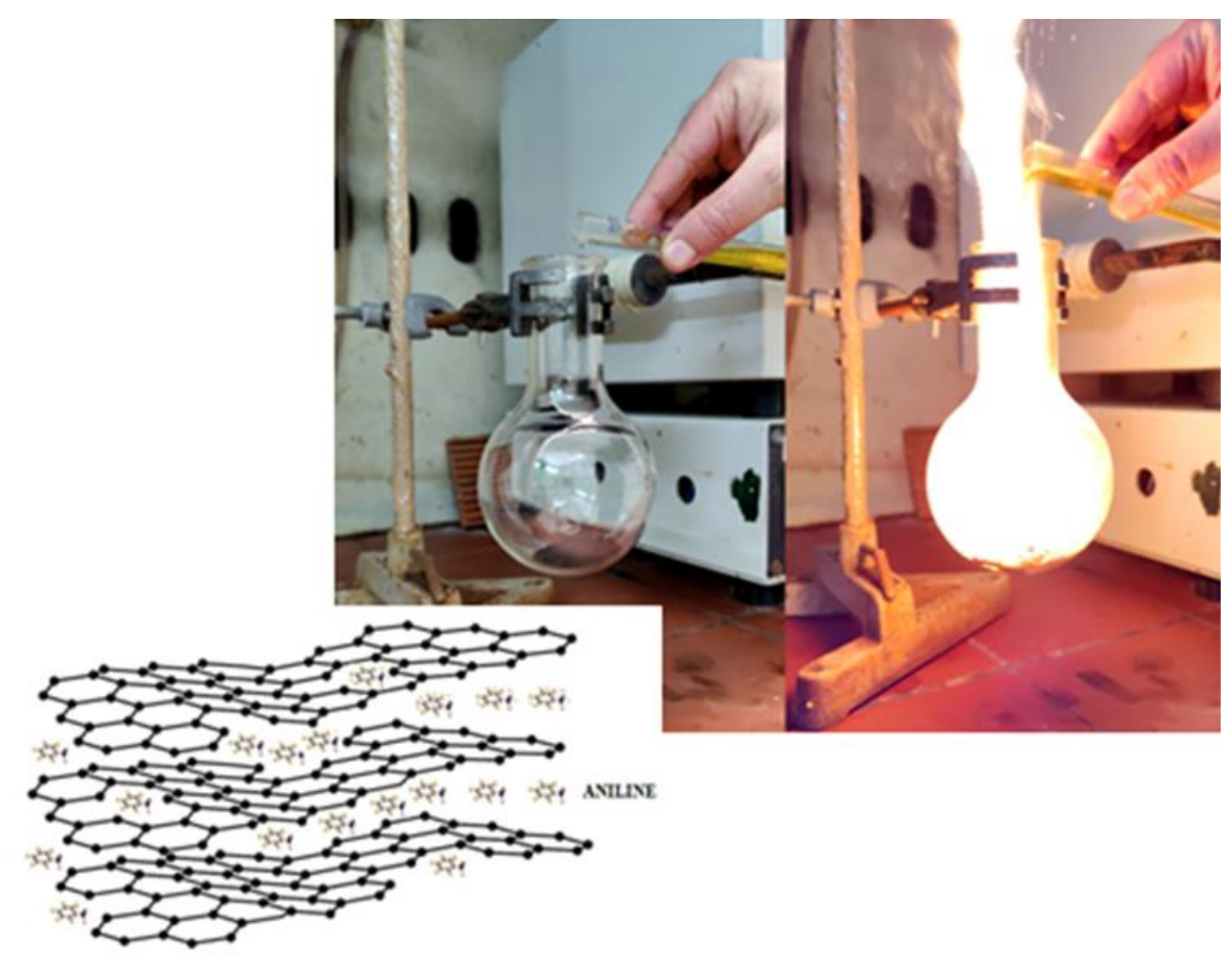

Figure 13. Aniline-intercalated carbon gives rise to a fast and bright ignition upon the addition of fuming $\mathrm{HNO}_{3}$. 


\section{Conclusions}

With its pros and cons, biomass waste carbonization in piranha solution appears to be a versatile new method for obtaining carbon materials with unusual properties not displayed by pyrolytically or hydrothermally derived carbons from biomass. As examples, we have mainly shown here the piranha solution-mediated carbonization of stale bread and spent coffee wastes, both discarded in landfills in large quantities without further processing. In both cases, carbonization proceeded fast and exothermically leading to carbon nanosheets at decent yields (25-35\%); the carbon nanosheets are amorphous, displaying turbostratic arrangement of incompletely crystallized layers, have a thickness of circa $3 \mathrm{~nm}$ and contain $\mathrm{O}, \mathrm{N}$ and $\mathrm{S}$ structural heteroatoms from the parent waste. Because of their relatively large interlayer spacing $(4.3 \AA)$, the obtained carbons react hypergolically upon contact with fuming nitric acid at ambient conditions. Since carbon hypergolicity is a rare phenomenon in literature, the present findings may stimulate further research in developing hypergolic carbons through the piranha solution treatment of biomass waste. Preliminary results with aniline intercalation indicate that the structural engineering of the derived carbons (surface area, porosity, lateral size and intercalation with hypergolically active molecules) may boost faster and brighter ignition, which is highly desired for rocket propellants. Such energetic carbons could be used as cheaper and less toxic alternative solid fuels in hypergolic propellant compositions.

Author Contributions: Conceptualization, A.B.B.; methodology, N.C., A.B.B.; validation, N.C., A.B.B., D.M., A.A., M.A.K. and D.G.; investigation, N.C., A.B.B., M.B., D.M., I.T., A.B., C.E.S., A.A., M.A.K. and D.G.; data curation, N.C., A.B.B., T.G., A.A., M.A.K., P.R. and D.G.; writing-original draft preparation, N.C. and A.B.B.; writing-review and editing, N.C., A.B.B. and D.G.; supervision, A.B.B. and D.G. All authors have read and agreed to the published version of the manuscript.

Funding: This study was funded by the project "National Infrastructure in Nanotechnology, Advanced Materials and Micro-/Nanoelectronics" (MIS-5002772), which was implemented under the action "Reinforcement of the Research and Innovation Infrastructure", funded by the Operational Programme "Competitiveness, Entrepreneurship and Innovation" (NSRF 2014-2020), and co-financed by Greece and the European Union (European Regional Development Fund). I. T. acknowledges the support by the Operational Programme Research, Development and Education-Project No. CZ.02.1.01/0.0/0.0/15_003/0000416 of the Ministry of Education, Youth and Sports of the Czech Republic. A. B. acknowledges funding from the Czech Science Foundation, project GA CR-EXPRO, 19-27454X.

Institutional Review Board Statement: Not applicable.

Informed Consent Statement: Not applicable.

Data Availability Statement: The data presented in this study are available on request from the corresponding author.

Acknowledgments: The authors greatly acknowledge Ch. Papachristodoulou for the XRD measurements, as well as, J. Stráská and C. Cepe for the TEM measurements.

Conflicts of Interest: The authors declare no conflict of interest.

\section{References}

1. Savaram, K.; Kalyanikar, M.; Patel, M.; Brukh, R.; Flach, C.R.; Huang, R.; Khoshi, M.R.; Mendelsohn, R.; Wang, A.; Garfunkel, E.; et al. Synergy of oxygen and a piranha solution for eco-friendly production of highly conductive graphene dispersions. Green Chem. 2015, 17, 869-881. [CrossRef]

2. Gaddam, R.R.; Vasudevan, D.; Narayan, R.; Raju, K.V.S.N. Controllable synthesis of biosourced blue-green fluorescent carbon dots from camphor for the detection of heavy metal ions in water. RSC Adv. 2014, 4, 57137-57143. [CrossRef]

3. Mei, Q.; Chen, J.; Zhao, J.; Yang, L.; Liu, B.; Liu, R.; Zhang, Z. Atomic oxygen tailored graphene oxide nanosheets emissions for multicolor cellular imaging. ACS Appl. Mater. Interfaces 2016, 8, 7390-7395. [CrossRef]

4. Ziegler, K.J.; Gu, Z.; Peng, H.; Flor, E.L.; Hauge, R.H.; Smalley, R.E. Controlled oxidative cutting of single-walled carbon nanotubes. J. Am. Chem. Soc. 2005, 127, 1541-1547. [CrossRef] [PubMed]

5. Wei, C.; Akinwolemiwa, B.; Wang, Q.; Guan, L.; Xia, L.; Hu, D.; Tang, B.; Yu, L.; Chen, G.Z. Mechano-fenton-piranha oxidation of carbon nanotubes for energy application. Adv. Sustain. Syst. 2019, 3, 1900065. [CrossRef] 
6. Lavagna, L.; Musso, S.; Ferro, G.; Pavese, M. Cement-based composites containing functionalized carbon fibers. Cem. Concr. Compos. 2018, 88, 165-171. [CrossRef]

7. Konkol, I.; Zwierczek, L.; Cenian, A. Biogas production from bakery wastes dynamics, retention time and biogas potential. J. Res. Appl. Agric. Eng. 2018, 63, 32-34.

8. Narisetty, V.; Cox, R.; Willoughby, N.; Aktas, E.; Tiwari, B.; Matharu, A.S.; Salonitis, K.; Kumar, V. Recycling bread waste into chemical building blocks using a circular biorefining approach. Sustain. Energy Fuels 2021, 5, 4842-4849. [CrossRef]

9. Campos-Vega, R.; Loarca-Piña, G.; Vergara-Castañeda, H.A.; Oomah, B.D. Spent coffee grounds: A review on current research and future prospects. Trends Food Sci. Technol. 2015, 45, 24-36. [CrossRef]

10. McNutt, J.; He, Q. Spent coffee grounds: A review on current utilization. J. Ind. Eng. Chem. 2019, 71, 78-88. [CrossRef]

11. Yuan, Y.; Ding, Y.; Wang, C.; Xu, F.; Lin, Z.; Qin, Y.; Li, Y.; Yang, M.; He, X.; Peng, Q.; et al. Multifunctional stiff carbon foam derived from bread. ACS Appl. Mater. Interfaces 2016, 8, 16852-16861. [CrossRef] [PubMed]

12. Cao, J.; Gao, Y.; Ma, Y. Facile preparation of activated carbon foam via pyrolysis of waste bread under $\mathrm{CO}_{2}$ atmosphere. Biomass Convers. Biorefinery 2019, 9, 521-529. [CrossRef]

13. Bhandari, S.; Mondal, D.; Nataraj, S.K.; Balakrishna, R.G. Biomolecule-derived quantum dots for sustainable optoelectronics. Nanoscale Adv. 2019, 1, 913-936. [CrossRef]

14. Andrade, T.S.; Vakros, J.; Mantzavinos, D.; Lianos, P. Biochar obtained by carbonization of spent coffee grounds and its application in the construction of an energy storage device. Chem. Eng. J. Adv. 2020, 4, 100061. [CrossRef]

15. Massaya, J.; Pickens, G.; Mills-Lamptey, B.; Chuck, C.J. Enhanced hydrothermal carbonization of spent coffee grounds for the efficient production of solid fuel with lower nitrogen content. Energy Fuels 2021, 35, 9462-9473. [CrossRef]

16. Asimakopoulos, G.; Baikousi, M.; Kostas, V.; Papantoniou, M.; Bourlinos, A.B.; Zbořil, R.; Karakassides, M.A.; Salmas, C.E. Nanoporous activated carbon derived via pyrolysis process of spent coffee: Structural characterization. Investigation of its use for hexavalent chromium removal. Appl. Sci. 2020, 10, 8812. [CrossRef]

17. Torrelio Martos, A.G.; López, E.P. Chemical composition, percent of dietary reference intake, and acceptability of gluten-free bread made from Prosopis nigra flour, added with hydrocolloids. Food Sci. Technol. 2018, 38, 619-624. [CrossRef]

18. Gouvea, B.M.; Torres, C.; Franca, A.S.; Oliveira, L.S.; Oliveira, E.S. Feasibility of ethanol production from coffee husks. Biotechnol. Lett. 2009, 31, 1315-1319. [CrossRef]

19. Chalmpes, N.; Spyrou, K.; Bourlinos, A.B.; Moschovas, D.; Avgeropoulos, A.; Karakassides, M.A.; Gournis, D. Synthesis of highly crystalline graphite from spontaneous ignition of in situ derived acetylene and chlorine at ambient conditions. Molecules 2020, 25, 297. [CrossRef]

20. Roh, J.-S. Structural study of the activated carbon fiber using laser raman spectroscopy. Carbon Lett. 2008, 9, 127-130. [CrossRef]

21. Saikia, B.K.; Boruah, R.K.; Gogoi, P.K. A X-ray diffraction analysis on graphene layers of Assam coal. J. Chem. Sci. 2009, 121, 103-106. [CrossRef]

22. Puech, P.; Kandara, M.; Paredes, G.; Moulin, L.; Weiss-Hortala, E.; Kundu, A.; Ratel-Ramond, N.; Plewa, J.-M.; Pellenq, R.; Monthioux, M. Analyzing the raman spectra of graphenic carbon materials from kerogens to nanotubes: What type of information can be extracted from defect bands? C 2019, 5, 69. [CrossRef]

23. Tsirka, K.; Katsiki, A.; Chalmpes, N.; Gournis, D.; Paipetis, A.S. Mapping of graphene oxide and single layer graphene flakesdefects annealing and healing. Front. Mater. 2018, 5, 37. [CrossRef]

24. Bourlinos, A.B.; Giannelis, E.P.; Sanakis, Y.; Bakandritsos, A.; Karakassides, M.; Gjoka, M.; Petridis, D. A graphite oxide-like carbogenic material derived from a molecular precursor. Carbon 2006, 44, 1906-1912. [CrossRef]

25. Chalmpes, N.; Moschovas, D.; Tantis, I.; Bourlinos, A.B.; Bakandritsos, A.; Fotiadou, R.; Patila, M.; Stamatis, H.; Avgeropoulos, A.; Karakassides, M.A.; et al. Carbon nanostructures derived through hypergolic reaction of conductive polymers with fuming nitric acid at ambient conditions. Molecules 2021, 26, 1595. [CrossRef]

26. Kouloumpis, A.; Vourdas, N.; Zygouri, P.; Chalmpes, N.; Potsi, G.; Kostas, V.; Spyrou, K.; Stathopoulos, V.N.; Gournis, D.; Rudolf, P. Controlled deposition of fullerene derivatives within a graphene template by means of a modified Langmuir-Schaefer method. J. Colloid Interface Sci. 2018, 524, 388-398. [CrossRef] [PubMed]

27. Yang, Z.; Dai, Y.; Wang, S.; Cheng, H.; Yu, J. In situ incorporation of a S, N doped carbon/sulfur composite for lithium sulfur batteries. RSC Adv. 2015, 5, 78017-78025. [CrossRef]

28. Carocho, M.; Morales, P.; Ciudad-Mulero, M.; Fernández-Ruiz, V.; Ferreira, E.; Heleno, S.; Rodrigues, P.; Barros, L.; Ferreira, I.C.F.R Comparison of different bread types: Chemical and physical parameters. Food Chem. 2020, 310, 125954. [CrossRef]

29. Pujol, D.; Liu, C.; Gominho, J.; Olivella, M.À.; Fiol, N.; Villaescusa, I.; Pereira, H. The chemical composition of exhausted coffee waste. Ind. Crops Prod. 2013, 50, 423-429. [CrossRef]

30. Huang, H.; Lu, Y.-C.; Wang, A.-J.; Liu, J.-H.; Chen, J.-R.; Feng, J.-J. A facile, green, and solvent-free route to nitrogen-sulfurcodoped fluorescent carbon nanoparticles for cellular imaging. RSC Adv. 2014, 4, 11872-11875. [CrossRef]

31. Jiao, C.; Zhang, Z.; Tao, J.; Zhang, D.; Chen, Y.; Lin, H. Synthesis of a poly(amidoxime-hydroxamic acid) cellulose derivative and its application in heavy metal ion removal. RSC Adv. 2017, 7, 27787-27795. [CrossRef]

32. Dong, Y.; Pang, H.; Yang, H.B.; Guo, C.; Shao, J.; Chi, Y.; Li, C.M.; Yu, T. Carbon-based dots co-doped with nitrogen and sulfur for high quantum yield and excitation-independent emission. Angew. Chem. Int. Ed. 2013, 52, 7800-7804. [CrossRef] [PubMed]

33. Chalmpes, N.; Kouloumpis, A.; Zygouri, P.; Karouta, N.; Spyrou, K.; Stathi, P.; Tsoufis, T.; Georgakilas, V.; Gournis, D.; Rudolf, P. Layer-by-layer assembly of clay-carbon nanotube hybrid superstructures. ACS Omega 2019, 4, 18100-18107. [CrossRef] [PubMed] 
34. Munjal, N.L. Ignition catalysts for furfuryl alcohol—Red fuming nitric acid bipropellant. AIAA J. 1970, 8, 980-981. [CrossRef]

35. Schneider, S.; Hawkins, T.; Rosander, M.; Vaghjiani, G.; Chambreau, S.; Drake, G. Ionic liquids as hypergolic fuels. Energy Fuels 2008, 22, 2871-2872. [CrossRef]

36. Kulkarni, S.G.; Bagalkote, V.S.; Patil, S.S.; Kumar, U.P.; Kumar, V.A. Theoretical evaluation and experimental validation of performance parameters of new hypergolic liquid fuel blends with red fuming nitric acid as oxidizer. Propellants Explos. Pyrotech. 2009, 34, 520-525. [CrossRef]

37. Kulkarni, S.G.; Bagalkote, V.S. Studies on pre-ognition reactions of hydrocarbon-based rocket fuels hypergolic with red fuming nitric acid as oxidizer. J. Energ. Mater. 2010, 28, 173-188. [CrossRef]

38. Da Silva, G.; Iha, K. Hypergolic Systems: A review in patents. J. Aerosp. Technol. Manag. 2012, 4, 407-412. [CrossRef]

39. Bhosale, M.V.K.; Kulkarni, S.G.; Kulkarni, P.S. Ionic liquid and biofuel blend: A low-cost and high performance hypergolic fuel for propulsion application. ChemistrySelect 2016, 1, 1921-1925. [CrossRef]

40. Titi, H.M.; Marrett, J.M.; Dayaker, G.; Arhangelskis, M.; Mottillo, C.; Morris, A.J.; Rachiero, G.P.; Friščić, T.; Rogers, R.D. Hypergolic zeolitic imidazolate frameworks (ZIFs) as next-generation solid fuels: Unlocking the latent energetic behavior of ZIFs. Sci. Adv. 2019, 5, eaav9044. [CrossRef]

41. Yuan, W.-L.; Zhang, L.; Tao, G.-H.; Wang, S.-L.; Wang, Y.; Zhu, Q.-H.; Zhang, G.-H.; Zhang, Z.; Xue, Y.; Qin, S.; et al. Designing high-performance hypergolic propellants based on materials genome. Sci. Adv. 2020, 6, eabb1899. [CrossRef] [PubMed]

42. Maggi, F.; Zadra, F. Combustion of nanoaluminum and magnesium in fuel-rich propellants. Propellants Explos. Pyrotech. 2020, 45, 724-729. [CrossRef]

43. Xu, Y.; Wang, Y.; Zhong, Y.; Lei, G.; Li, Z.; Zhang, J.; Zhang, T. High-energy metal-organic frameworks with a dicyanamide linker for hypergolic fuels. Inorg. Chem. 2021, 60, 5100-5106. [CrossRef] [PubMed]

44. Chalmpes, N.; Bourlinos, A.B.; Talande, S.; Bakandritsos, A.; Moschovas, D.; Avgeropoulos, A.; Karakassides, M.A.; Gournis, D. Nanocarbon from rocket fuel waste: The case of furfuryl alcohol-fuming nitric acid hypergolic pair. Nanomaterials $2021,11,1$. [CrossRef] [PubMed]

45. Chalmpes, N.; Moschovas, D.; Bourlinos, A.B.; Spyrou, K.; Vasilopoulos, K.C.; Avgeropoulos, A.; Karakassides, M.A.; Gournis, D Hypergolic ignition of 1,3-cyclodienes by fuming nitric acid toward the fast and spontaneous formation of carbon nanosheets at ambient conditions. Micro 2021, 1, 15-27. [CrossRef]

46. Chalmpes, N.; Bourlinos, A.B.; Šedajová, V.; Kupka, V.; Moschovas, D.; Avgeropoulos, A.; Karakassides, M.A.; Gournis, D. Hypergolic materials synthesis through reaction of fuming nitric acid with certain cyclopentadienyl compounds. $C 2020,6,61$. [CrossRef]

47. Yan, Q.-L.; Gozin, M.; Zhao, F.-Q.; Cohen, A.; Pang, S.-P. Highly energetic compositions based on functionalized carbon nanomaterials. Nanoscale 2016, 8, 4799-4851. [CrossRef]

48. Chalmpes, N.; Spyrou, K.; Vasilopoulos, K.C.; Bourlinos, A.B.; Moschovas, D.; Avgeropoulos, A.; Gioti, C.; Karakassides, M.A.; Gournis, D. Hypergolics in carbon nanomaterials synthesis: New paradigms and perspectives. Molecules 2020, 25, 2207. [CrossRef]

49. Turkevich, L.A.; Fernback, J.; Dastidar, A.G.; Osterberg, P. Potential explosion hazard of carbonaceous nanoparticles: Screening of allotropes. Combust. Flame 2016, 167, 218-227. [CrossRef]

50. Huston, J.L.; Scott, R.G.; Studier, M.H. Reaction of fluorine gas with coal and the aromaticity of coal. Fuel 1976, 55, 281-286. [CrossRef]

51. Ajayan, P.M.; Terrones, M.; Guardia, A.d.1.; Huc, V.; Grobert, N.; Wei, B.Q.; Lezec, H.; Ramanath, G.; Ebbesen, T.W. Nanotubes in a flash-ignition and reconstruction. Science 2002, 296, 705. [CrossRef] [PubMed]

52. Cuzzillo, B.R.; Pagni, P. The myth of pyrophoric carbon. Fire Saf. Sci. 2000, 6, 301-312. [CrossRef]

53. Baikousi, M.; Chalmpes, N.; Spyrou, K.; Bourlinos, A.B.; Avgeropoulos, A.; Gournis, D.; Karakassides, M.A. Direct production of carbon nanosheets by self-ignition of pyrophoric lithium dialkylamides in air. Mater. Lett. 2019, 254, 58-61. [CrossRef]

54. Spyrou, K.; Kang, L.; Diamanti, E.K.; Gengler, R.Y.; Gournis, D.; Prato, M.; Rudolf, P. A novel route towards high quality fullerene-pillared graphene. Carbon 2013, 61, 313-320. [CrossRef]

55. Rastogi, R.P.; Munjal, N.L. Mechanism and kinetics of pre-ignition reactions: Part I-aniline-red fuming nitric acid propellants. Indian J. Chem. 1966, 4, 463-468.

56. Gune, S.G.; Kulkarni, S.G.; Panda, S.P. Synergistic hypergolic ignition of solid substituted anilines mixed with magnesium powder and red fuming nitric acid. Combust. Flame 1985, 61, 189-193. [CrossRef]

57. Chalmpes, N.; Asimakopoulos, G.; Spyrou, K.; Vasilopoulos, K.C.; Bourlinos, A.B.; Moschovas, D.; Avgeropoulos, A.; Karakassides, M.A.; Gournis, D. Functional carbon materials derived through hypergolic reactions at ambient conditions. Nanomaterials 2020, 10, 566. [CrossRef]

58. Bourlinos, A.B.; Karakassides, M.A.; Simopoulos, A.; Petridis, D. Synthesis and characterization of magnetically modified clay composites. Chem. Mater. 2000, 12, 2640-2645. [CrossRef]

59. Dallas, P.; Bourlinos, A.B.; Petridis, D.; Boukos, N.; Papadokostaki, K.; Niarchos, D.; Guskos, N. Synthesis and characterization of 2-D and 3-D covalent networks derived from triazine central cores and bridging aromatic diamines. Polymer 2008, 49, 1137-1144 [CrossRef] 